This article is published as: Vanmaercke M, Poesen $\mathrm{J}$, Verstraeten $\mathrm{G}$, Maetens $\mathrm{W}$, de Vente J (2011) Sediment yield as a desertification risk indicator. Science of the Total Environment 409: $1715-1725$.

\title{
Sediment Yield as a Desertification Risk Indicator
}

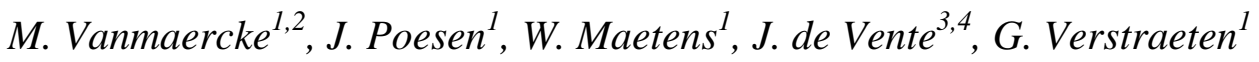

\author{
${ }^{1}$ Geography Division - K.U.Leuven, Belgium
}

${ }^{2}$ Fund for Scientific Research-Flanders, Belgium

${ }^{3}$ Estación Experimental de Zonas Áridas, EEZA-CSIC, Desertification and Geoecology Department, Almeria, Spain

${ }^{4}$ School of Geosciences, University of Aberdeen, Aberdeen, UK

\begin{abstract}
Soil erosion is often regarded as one of the main processes of desertification. This has lead to the use of various desertification indicators that are related to soil erosion. Most of these indicators focus, however, on small spatial units, while little attention has been given to the amount of sediment exported at the catchment scale. Such a small spatial unit approach neglects the transfer of sediment through catchments as well as the scale-dependency of erosion processes. Furthermore, this approach does not consider important off-site impacts of soil erosion, such as sediment deposition in reservoirs, flooding as well as ecological impacts. This study aims to illustrate the importance of also considering catchment sediment yield (SY, $\left.\mathrm{t} \mathrm{km}^{-2} \mathrm{y}^{-1}\right)$ in desertification assessment studies. Based on recently established databases of SY and soil loss rates in Europe and examples from previous studies, we illustrate that soil erosion rates at the plot scale are not representative for catchment SY, as they are often several orders of magnitude smaller. Also, the erosion response of catchments to changes in land use or climate often differs strongly from responses to those changes at the plot scale. We further discuss several of the impacts of SY and their link with desertification: i.e. the sedimentation of reservoirs, problems related to flooding, catchment hydrology, export of nutrients and ecological implications.
\end{abstract}

Using earlier established criteria we evaluate the potential for using catchment SY as a desertification indicator and conclude that this could give an important added value to 
desertification studies. SY, used in combination with other indicators, allows the identification of other sediment sources than those considered at the plot scale and can reflect the results of desertification processes over longer time periods than periods over which assessments at the plot scale have been made. We argue therefore, that SY is a strong complementary indicator of desertification providing valuable information on the catchment response to changes in drivers of desertification.

\section{Introduction}

Desertification is defined by the United Nation Convention to Combat Desertification as "land degradation in arid, semi-arid, and dry sub-humid areas resulting from climatic variations and human activities" (UNEP, 1994). It is seen as the result of a series of natural and anthropogenic processes, leading to gradual environmental degradation or loss of the land's biological or economic productivity. These processes include degradation of the vegetation cover, biological, physical and chemical degradation of soils, water erosion and wind erosion (Rubio \& Bochet 1998). Over the last decades, methods have been developed to analyze desertification processes as well as their response to biophysical and socioeconomic drivers of desertification. One of these methods is the use of indicators. Indicators have the advantage of providing simplified, synthetic information on the state and tendency of the complex desertification process (Rubio \& Bochet 1998) and have been used in various research and mitigation programs (e.g. Kosmas et al. 2003). An extensive list of potential indicators to assess the various physical, ecological, economic, social and institutional aspects of desertification was developed in the DESERTLINKS-project, based on a review of earlier studies (Kosmas et al. 1999, Brandt et al. 2006). The resulting DIS4ME Indicator System (Desertlinks 2004), provides information on 148 indicators of relevance to Mediterranean desertification and was designed to provide a tool to enable users from a wide range of backgrounds 1) to identify where desertification is a problem; 2) to assess how critical the problem is; and 3) to better understand the processes of desertification and how these respond to changes in biophysical and socioeconomic drivers. This indicator system was used in various other recent research projects (e.g. DESERTNET 2008; LUCINDA 2008; FAOLADA 2010; DESIRE 2010). Soil erosion by water is often regarded as one of the most intense and widespread desertification processes (e.g. López-Bermúdez 1990; Pimentel et al. 1995; Poesen 1995; Rubio \& Bochet 1998). Table 1 gives an overview of potential indicators from the DIS4ME Indicator system that can be related to this process. Although these indicators can be applied to large regions, the majority of these indicators can be considered 
as 'on-site' indicators, meaning that the state or value of the indicator at a location is not influenced by conditions at other locations. The minimal spatial scale at which values for these indicators is assessed is generally the plot or hillslope scale. Of the 70 indicators listed in table 1 , only 5 can be considered to reflect the integrated result of factors and processes at the catchment scale (dam sedimentation, drainage density, flooding frequency, floodplain and channel morphology and rainfall-runoff relationship). For two of these indicators (dam sedimentation and rainfall-runoff relationship), no detailed description of typical values, thresholds, or interpretation was given. This illustrates that soil erosion is mainly considered as an on-site process in studies on desertification, while generally little attention is given to the downstream impacts of soil erosion or the combined effect of soil erosion, sediment transport and deposition (i.e. the catchment sediment yield).

Also the UNCCD Conference of the Parties (COP) decided recently to accept a set of eleven impact indicators to monitor desertification that are to be used in the annual country status reports (UNCCD 2010). These proposed indicators focus strongly on on-site erosion, but do not consider the integrated effect of soil erosion at the catchment scale or the off-site consequences of soil erosion.

Various studies have, however, indicated that the extrapolation from soil erosion rates at the plot scale to catchment sediment yields ( $\mathrm{SY}, \mathrm{t} \mathrm{km} \mathrm{y}^{-1}$ ) or from one catchment to another poses many difficulties (e.g. Walling 1983; de Vente \& Poesen 2005; de Vente et al. 2007). Also, the response of river systems to catchment disturbances (e.g. climate changes or human interventions) is generally known to be complex and difficult to predict (e.g. Schumm et al. 1976; Walling \& Kleo 1979; Church \& Slaymaker 1989; Walling 2006; Owens et al. 2010; Trimble 2010). SY at the catchment scale and its response to changes are, however, of great importance as it relates to many environmental and management issues (see Owens et al. 2005 for an overview) and are also of great relevance in the framework of desertification assessment.

This paper argues that (variation in) SY at the catchment scale provides important and highly relevant information on ongoing desertification processes and impacts. We first discuss some essential differences in terms of magnitude between soil loss at the plot scale and catchment SY, as well as their respective response to disturbances. We then illustrate how catchment SY relates to various problems that are closely linked to desertification. Finally, we evaluate the possiblity to use SY as a desertification indicator and discuss how it should be interpreted.

\section{The relevance of sediment yield in the desertification process}




\section{II.1. Scale dependency of soil erosion processes}

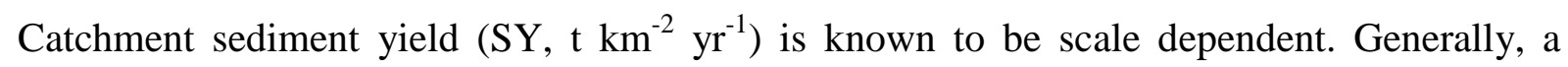
negative relationship is expected between catchment area $\left(\mathrm{A}, \mathrm{km}^{2}\right)$ and $\mathrm{SY}$ due to a decrease in topsoil erosion rates on more gentle slopes and an increased probability of sediment deposition with an increase in catchment size (Walling 1983). SY is therefore often assessed by multiplying the estimated total erosion rate on hillslopes with a sediment delivery ratio (SDR), which is generally estimated as a function of catchment area, topography and/or the drainage network (e.g. Robinson 1977). This approach has, however, received a lot of criticism, mainly due to its black box nature (Walling 1983; de Vente and Poesen 2005; de Vente et al. 2007). Especially in (semi)-arid and Mediterranean environments (i.e. environments with a potential desertification risk) SDRs are hard to apply, as they are very variable and difficult to assess. Studies of A-SY relationships for various (semi-)arid regions indicated both negative trends, with often much stronger decrease of SY with A than in humid regions, as well as insignificant or even positive relationships (Walling \& Kleo 1979; Verstraeten et al. 2006; de Vente et al. 2007). In a study of SY and its scale dependence in Europe, Vanmaercke et al. (2010a subm.) illustrated that SY is generally much higher in the Mediterranean, Anatolian and Alpine regions than in other geographical regions. Further, no clear negative A-SY relationships were found for these regions, even within the same major river system.

One of the major problems with the SDR concept is that sediments may originate from various sources, such as gullies, riverbanks and landslides, and not only from topsoils (i.e. through splash, sheet and rill erosion). As spatial units increase, other sediment sources (such as gully erosion, bank erosion or mass movements) may become dominant (Walling 1983; de Vente et al. 2007). Gully erosion, for example, only occurs if a specific slope and drainage area threshold is exceeded (Vandekerckhove et al. 2000; Poesen et al. 2003). Gullies not only function as a sediment source but also increase sediment connectivity in the landscape. Therefore, their contribution to SY at the catchment scale can amount up to $80 \%$, especially in semi-arid environments (Poesen et al. 2003; de Vente et al 2008).

In figure 1, the cumulative frequency distribution of measured catchment SY in Europe is compared with the cumulative distribution of soil loss rates, measured at the plot scale ("plot data'). SY-data were assembled from an extensive literature review (Vanmaercke et al. 2010a; subm.). Plot data were derived from a recently established dataset on runoff and soil loss rates, measured on runoff plots (Maetens et al. 2009; Maetens et al. in prep.). Only plots without soil and water conservation measures were considered in this figure, so that the data 
would represent as much as possible the conventional land use conditions at the hillslope scale. Plot and SY data were grouped into two categories, based on the LANMAP2 climatic classification of Europe (Metzger et al. 2005; Mücher et al. 2006): Mediterranean and NonMediterranean (consisting of the Boreal, Atlantic and Continental climatic regions). Figure 1 illustrates that soil loss rates are generally larger than catchment sediment yields in the NonMediterranean regions, which is consistent with the traditional sediment delivery concept, but about one order of magnitude lower in the Mediterranean regions. The difference is partly explained because Mediterranean soil loss rates are generally lower than Non-Mediterranean rates. This is agrees with previous studies, indicating that soil erodibility is generally lower for Mediterranean than for temperate climatic zones (Salvador Sanchis et al. 2008). Furthemore, Mediterranean soils have often a larger fraction of rock fragments (Poesen et al. 1995), which significantly reduce the soil erodibility (Poesen et al. 1994; Sanchis et al. 2008). However, catchment sediment yields are also higher for the Mediterranean than for the NonMediterranean regions. This provides a clear indication that sheet and rill erosion processes are generally not the major sediment sources in Mediterranean regions.

Similar results were found when a comparison was made between the SY of 26 small catchments in Europe and the predicted soil erosion risk by the PESERA model (Kirkby et al. 2004; 2008). Catchment SY data was collected from various sources, based on a literature review. The result is shown in Figure 2, while Table 2 includes the major characteristics and original source of the catchments data. To allow a better comparison, only SY of catchments smaller than or equal to $1 \mathrm{~km}^{2}$ were considered, as PESERA soil losses were calculated for a 1 $\mathrm{km}^{2}$ grid resolution and the model does not consider sediment routing between the pixels (Kirkby et al. 2004). Except the availability of a PESERA erosion rate estimation, no other selection criteria were used for the catchment data. Data were classified into Mediterranean \& Non-Mediterranean groups according to the LANMAP2 climatic classification (Metzger et al. 2005; Mücher et al. 2006). The PESERA model is a physically based model that was essentially developed to estimate sheet and rill erosion. The model is built around a partition of precipitation into components for overland flow, evapo-transpiration and changes in soil moisture storage. Transpiration is used to drive a generic plant growth model, while the runoff is used in combination with other factors (such as soil properties) to predict the erosion. A detailed description of the model is given in Kirkby et al. 2008.

The comparison indicates that for most Non-Mediterranean catchments PESERA erosion rates are within one order of magnitude of the measured SY. In Mediterranean catchments, however, SY are generally much higher than the predicted erosion rates (figure 2). de Vente et 
al. (2008) made a similar comparison for 61 larger catchments in Spain and noted that for most basins PESERA soil erosion rates vary between fifty and close to zero percent of the measured SY. Part of the deviations between the observed SY and the PESERA erosion rates can most likely be attributed to errors in the model. A validation of the model for several regions in Europe, indicated that errors on the used input data (e.g. rainfall data and land use maps) have a significant impact on the quality of erosion estimates (Van Rompaey et al. 2003). Nevertheless, these errors can not really explain why observations for the NonMediterranean catchments cluster around the 1:1 line and SY for the Mediterranean zone are generally much higher than the predicted erosion rates. The different trend for Mediterranean and Non-Mediterranean catchments is most likely explained by the processes considered by the model. Soil erosion predicted by PESERA is expressed as the sediment delivered to the base of the hillside by sheet and rill erosion, while permanent gully, channel erosion, mass movements, channel delivery processes and channel routing are explicitly not considered. The large observed deviations for the Mediterranean zone are therefore a further indication that other sediment sources are often much more important in these regions.

Several other studies have illustrated the large contribution of sediment sources other than topsoil erosion to SY in Mediterranean environments (e.g. Poesen \& Hooke 1997; Cammeraat 2004; de Vente \& Poesen 2005). An extreme example is provided for the Isabel II reservoir, near Nijar, S.E. Spain (Roquero 1991). This $31 \mathrm{~m}$ high dam was built in 1850 for irrigation purposes, has an upstream area of $18 \mathrm{~km}^{2}$ and had an orginal capacity of $2 \times 10^{6} \mathrm{~m}^{3}$. The reservoir was silted up in only six years (Roquero 1991). Sediment source determination, based on magnetic properties of the sediments, indicated that only a minority of the reservoir siltation was due to top soil erosion processes, whereas the majority of trapped sediments consisted of unweathered schist bedrocks, which were most likely produced by gully erosion processes ( $\mathrm{Yu} \&$ Oldfield 1993). The Puentes reservoir (SE Spain) provides a similar example. A study of Cs-137 concentration in the sediments retained by this reservoir indicated that about $60 \%$ of the sediments have a subsurface origin, pointing towards an important contribution of gully and bank erosion processes (Plata-Bedmar et al. 1997).

These examples clearly indicate that soil loss rates measured at the plot scale are not representative for sediment yield at another scale. Also the SY from one catchment can not straightforwardly be extrapolated to another catchment or scale, since other sediment sources can be active. Nevertheless, desertification due to water erosion is often only assessed, using measurements at the plot scale. 


\section{II.2. The catchment response to disturbances in land use and climate}

Apart from their scale dependence, catchment sediment yield in (semi-)arid areas is characterized by a sensitive and complex response to disturbances, such as land use changes or extreme climatic events. This sensitivity is sometimes described as the 'historical hangover' effect (Douglas 1967). Arid and semi-arid catchments are generally characterized by a fragile and delicately balanced ecosystem. Disruptions of this ecosystem, e.g. due to overgrazing, vegetation clearance, reforestation or other changes in land management, may produce far-reaching changes in the basin conditions and response and recovery may take a long period of time, if indeed it ever takes place (Walling \& Kleo 1979).

The complexity of the response to catchment disturbances is closely linked to the scale issues discussed above. It is known that disturbances in the catchments may be buffered by temporal deposition of sediments or activation of other erosion processes, leading to a delayed but often long lasting response in catchment SY (e.g. Church \& Slaymaker 1989; Trimble 2010). Catchment SY therefore often reflects the integrated effect of various processes over longer time periods. The responses of SY to disturbances are, however, difficult to assess, both in magnitude and response time, as the link between disturbance and response may not be straightforward (Owens et al. 2010). This seems especially the case in (semi)-arid environments. Cammeraat (2004) illustrates how hydrological and erosion responses in semiarid catchments are controlled by scale-dependent thresholds of precipitation depending on various factors such as local soil characteristics, previous rainfall events and vegetation patterns. Rainfall events can have various effects on SY. Whereas large rainfall events can generate a lot of sediment from hillslopes, that sediment is not always exported to the catchment outlet, but can be stored at various places, such as terraces or river channels. However, when a certain treshold value is exceeded or when e.g. land use changes significantly, these stored sediment can be released and can result in high sediment yields (Cammeraat 2004).

Also at longer time scales, the storage and reactivation of sediments within the catchment can lead to complex responses in catchment SY. Colluvial and alluvial deposits can buffer changes in sediment supply at the catchment scale (e.g. Verstraeten et al. 2009; Trimble 2010). They can serve as a sink for sediments, eroded upstream, but can become a sediment source when the upstream sediment supplies decline. As a consequence, improvements in land use management or the implementation of soil and water conservation measures do not necessary result immediatly in lower sediment yields. In the northern Ethiopian highlands, for instance, long and intense human induced erosion has lead to extensive alluvial deposits. 
During the last decades, important efforts in land use management and soil and water conservation have been made (Nyssen et al. 2004). Repeated photo surveys indicate that sheet and rill erosion rates have decreased over the decades due to an improved vegetation cover (Nyssen et al. 2008). However, at the scale of medium-sized (i.e. 100-5000 km²) catchments no clear effect of soil and water conservation measures on SY was found so far (Vanmaercke et al. 2010b). Although other factors (such as rainfall patterns) also play an important role, this is partly due to the reactivation of alluvial sediments. This is confirmed by the repeated photo surveys, indicating that (ephemeral) river channels have significantly incised over the last decades (Nyssen et al. 2008).

Also in the Mediterranean region, complex interactions between climate and the long history of human occupation and soil erosion has lead to large volumes of alluvial deposits (e.g. Bintliff 2002; Hooke 2006), but also in thin and stony soils (e.g. Lasanta et al. 2006; GarciaRuíz et al. 2010; Clapp et al. 2000). These soils will produce runoff but much less sediments (Poesen et al. 1994; Govers et al. 2006; Salvador Sanchis et al. 2008). As a result, the alluvial deposits can be remobilized, contributing to the SY of many Mediterranean catchments. This is in agreement with the generally lower soil loss rates at the plot scale compared to catchment sediment yields (figure 1,2).

These examples illustrate the importance of spatial scale, response time and their implications for SY. Catchment SY represents the integrated result of all sediment sources and sinks and their interactions. Including SY in desertification indicator approaches therefore helps to avoid the risk of not considering the most dominant erosion processes. Furthermore, catchment SY can provide insight on desertification processes over longer time periods than studies at the plot scale, as previous disturbances may still have an impact on the present sediment fluxes. Studying SY at the catchment scale can therefore provide important complementary information to desertification studies that focus only on the plot scale. It should be noted, however, that catchment SY alone is not sufficient to assess desertification by soil erosion. Catchments with a low SY are not always catchments without desertification problems. Important erosion hotspots may occur in these catchments; however their effect on SY may be minimal due to low connectivity, buffering and aggregation of zones with high erosion rates with zones having low erosion rates (e.g. Nadal-Romero et al. accepted.).

\section{Off-site impacts of soil erosion in relation to desertification}

Including SY in desertification assessment studies is not only important to improve our understanding about ongoing land degradation processes. It is also highly relevant as soil 
erosion can have many off-site consequences that are closely linked to desertification problems. Land degradation (and hence desertification) generally refers to the decline of actual and potential benefits that land use units provide (e.g. Oldeman et al. 1991). The costs of land degradation are often estimated by assessing the loss of production capacity due to onsite erosion processes (e.g. Schertz 1983; Hein 2007), while the off-site consequences are mostly ignored. This can lead to significant underestimations of the total cost of land degradation as high sediment yields can also lead (often indirect) to a loss of productivity and ecosystem services. This is further discussed in this section.

\section{III.1. Reservoir sedimentation}

One of the most important off-site impacts of soil erosion is the siltation of reservoirs, as it directly links with water availibility. Water is one of the main factors limiting production and settlement in drylands. Lack of water is a fundamental cause of many problems of desertification and environmental degradation (Sharma 1998).

Over the last decades, the total number of large dams has increased tremendously worldwide (Vörösmarty et al. 2003). Large dams (> $15 \mathrm{~m}$ high) have been constructed at a rate of 1.2 dams/day since 1930 (Basson 2008). This large-scale dam construction is a response to the increased demand in electricity and water supply. It can be expected that especially in arid and semi-arid regions, the need for water supplies will increase. For example, de Wit \& Stankiewicz (2006) demonstrate that, based on predicted changes in rainfall regime, a decrease in perennial drainage will affect $25 \%$ of Africa's present surface water access by the end of this century. The decrease in precipitation will mainly affect the semi-arid regions of Africa, where a $10 \%$ decrease in rainfall can cause a decrease of surface drainage by $50 \%$ (de Wit \& Stankiewicz 2006). Whereas the rate of reservoir construction has generally decreased over the last two to three decades, the growth in reservoir capacity in the Middle East has set in later than in other regions. Presently, construction in this region is still carried out on a larger scale than in most other regions (Basson 2008).

Semi-arid regions not only have a larger need for reservoirs. They are also generally more susceptible for reservoir sedimentation problems. Reservoir sedimentation rates are controlled by the sediment input into the reservoir (i.e. the product of A and SY) and the trapping effectiveness of the reservoir (TE (\%), i.e. the fraction of sediment input that is effectively trapped by the reservoir). As discussed in the previous section and indicated in numerous studies, catchments in semi-arid and Mediterranean regions are often characterized by high sediment yields and high annual reservoir capacity losses (e.g. Walling \& Kleo 1979; 
Verstraeten et al. 2006; Vanmaercke et al. 2010a; subm.; Nadal-Romero accepted.; see also figure 2). Furthermore, reservoirs in (semi-)arid regions are often more susceptible to sedimentation problems, as they are often constructed to provide a continuous water supply in ephemeral river systems. Therefore, they often have relatively larger reservoir capacities and hence higher TEs than reservoirs with a main focus on electricity supply (Vörösmarty et al., 2003).

Based on the ICOLD World Register of Dams (WRD) and a global denudation map, Basson (2008) estimated a global average reservoir capacity loss of $0.8 \%$ per year. Many countries in (semi-) arid regions, such as Iran, Morocco, Pakistan, Sudan and Tunisia, have sedimentation rates above this average value (White 2001; Basson 2008). The annual capacity loss of reservoirs are, however, subjected to a lot of variation which is not reflected in these average values per country. Figure 3 displays the annual capacity loss of reservoirs in Mediterranean Europe, as a function of their initial reservoir capacity. Data were extracted from previously established datasets on reservoir sedimentation and SY in Europe (Verstraeten et al. 2006; Vanmaercke et al. 2010a; subm.). The average reservoir capacity loss of this dataset is $2.5 \%$, which is more than three times the estimated global average reported by Basson (2008). However, the variability is large and spans more than 4 orders of magnitude. Furthermore, a significant negative relationship was found between the initial reservoir capacity and the annual capacity loss. In figure 3, a distinction was made between reservoirs that are included in the ICOLD WRD and reservoirs that are not included. Reservoirs that are not included are generally smaller and are characterized by generally higher capacity losses. The calculated average of Basson (2008) is only based on data of larger dams, while smaller inpoundments are not considered. Nevertheless, these smaller reservoirs are highly relevant in the context of desertification as they are often used for local irrigation purposes and water supplies. For instance in the semi-arid tropical highlands of Ethiopia, significant achievements were made, mainly from 1994 to 2002, on the development of agriculture through irrigation by employing seasonally harvested runoff using earth dams. However, sediment deposition threatens the functioning of many of these constructed earthen dams, with reservoir capacity losses of up to $4 \%$ per year (Haregeweyn et al. 2006). Based on the ICOLD WRD Ethiopia has, however, only an average capacity loss of $0.52 \%$ per year (Basson 2008).

Nonetheless, the world overview of Basson (2008) clearly indicates that mainly drought affected countries will be confronted with reservoir siltation problems. Although many arid and semi-arid regions have a large potential for water development, the real problem is often the lack of an integrated water management policy (Sharma 1998). This need has already been 
expressed in several studies on reservoir sedimentation problems of (semi-)arid regions (e.g. Lahlou 1996; Sharma 1998; Haregeweyn et al. 2006; Vanmaercke et al 2010b; Vanmaercke et al. subm.).

The total costs associated with reservoir sedimentation are difficult to assess, since this depend on various specific characteristics of the reservoir and its mode of operation. Palmieri et al. (2001) provided a framework to assess the costs of reservoir sedimentation. A rudimentary way to assess the cost of reservoir sedimentation is by estimating the price to remove the trapped sediments from the reservoir (e.g. Hein 2007; Kuhlman et al. 2010). This cost is strongly determined by the availability of excess water flows which can be used to flush sediments out of the reservoir. For most reservoirs flushing is not economically feasible (Palmieri et al. 2001) and sediments should be dredged from the reservoir. This is certainly the case in (semi-)arid regions, where most reservoirs were constructed to mitigate water shortage (e.g. Sharma 1998; Vörosmarty et al. 2003; Haregeweyn et al. 2006). Also the average cost of to dredge one cubic meter of sediments is difficult to assess, as this strongly depends on the time and area of consideration. Hein (2007) cite a cost of $€ 3 \mathrm{~m}^{-3}$ for dredging operation in the earlier mentioned Puentes reservoir. However, the reference to this price dates back to 1990. Kuhlman et al. (2010) mention a price of $€ 6.1 \mathrm{~m}^{-3}$, based on a reference of 2004 (Morschel et al., 2004 in Kuhlman et al., 2010).

Based on a very crude extrapolation of sediment deposition rates in the United States and an unrealistically high bulk density of $2.7 \mathrm{t} \mathrm{m}^{-3}$, Kuhlman et al. (2010) estimate the annual reservoir siltation rate in Europe at 93 million $\mathrm{m}^{3} \mathrm{y}^{-1}$. By considering $90 \%$ of this siltation rate as a result of water erosion and a dredging cost of $€ 6.1 \mathrm{~m}^{-3}$, they estimate the cost of reservoir siltation in Europe at $€ 567$ million per year without considering the costs associated with the disposal of the dredged material. This price is most probably a serious underestimation: for all reservoirs considered in Figure 3 the sum of all annual capacity losses is already 73 million $\mathrm{m}^{3} \mathrm{y}^{-1}$. As these reservoirs represent only an estimated $7.5 \%$ of the total reservoir capacity in the Mediterranean region of Europe (Verstraeten et al. 2006), the actual cost can easily be one or two orders of magnitudes higher. Accurate estimations on the cost of reservoir siltation are, however, currently lacking.

\section{III.2. Problems related to flooding and catchment hydrology}

Sediment export and flood events are often closely linked to each other. The occurrence of floods can have a major impact on SY, especially in (semi-)arid environments as the episodic nature of floods and the lack of a good vegetation cover provide opportunities for very large 
volumes of sediments to be transported (e.g. Schick et al. 1997; Vanmaercke et al. 2010b). In the Israelian Negev highlands floods lead to the headcut migration of gullies in valley bottoms. These gully incisions are a key factor in desertification as they lead to the degradation of the most productive areas. The expanding gully network not only leads to the loss of productive soil, but also prevents the floodwater of irrigating the valley bottoms as the floodwater is channeled into the narrow gullies. This leads to a sharp estimated drop of 7090\% in floral biomass (Avni 2005).

As discussed above, the formation of gullies can contribute significantly to SY, but depends on tresholds of slope and drainage area which are not reached at the plot scale (Vandekerckhove et al. 2000; Poesen et al. 2003). Studying SY at the catchment scale can therefore provide important indications of desertification caused by loss of fertile soil due to a range of erosion processes, flooding and changes in catchment hydrology.

The sediment load of a river also has an influence on river morphology, which on its turn can have affect its flooding regime (Baker et al. 1988; Owens et al. 2005). Furthemore, the high sediment loads of floods is one of the main reasons that make flood regulation schemes often difficult to perform. Schick et al. (1997) illustrate that sediment in flood discharge is capable of disrupting drainage regulators such as check dams and diversions. Based on their experience in southern Israel, they advise that control measures, such as settling basins, channel diversions, and street floodways, must be designed to cope with sediment loads of up to $10 \%$ concentration or more. High sedimentation rates in reservoirs can also increase the risk of flooding, as the delta deposits at the entrance of a reservoir can cause a rise in water level of the rivers upstream from the reservoir (Lahlou 1996; Morris et al. 2008). SY should therefore be certainly considered in flood mitigation programs.

\section{III.3 Problems related to nutrients and ecology}

The transport and deposition of sediments may have important ecological impacts related to pollution, ecological habitat destruction, the loss of nutrients or eutrophication (Owens et al. 2005). Many of these issues are also important in the context of desertification, as environments with low precipitation generally have very fragile ecosystems that are sensitive to change (Walling \& Kleo 1979). Fonseca et al. (1998) investigated the trapped sediments of two reservoirs in Portugal and found that sediments of both reservoirs had high nutrient levels, with values exceeding those of the original soils. Haregeweyn et al. (2008) report similar results for 13 reservoirs in the semi-arid northern Ethiopian highlands, where sediments from the reservoirs were richer in nutrients than the original soils from where they 
eroded. This enrichment in nutrients is associated with the preferential transport of nutrients bound to finer soil fractions and the dissolution of parent material and its transport via runoff (Haregeweyn et al. 2008). These nutrient losses may cause a large threat for crop production, as soil fertility is often already low, and are associated with large costs (Haregeweyn et al. 2008). Furthermore, the nutrient-rich sediments in reservoirs can cause eutrophication and water quality problems, particularly in drinking water reservoirs (Lahlou 1996; Fonseca et al. 1998). Dredging the sediments and using it as fertilizer could provide a solution, if this is economically feasible (Fonseca et al. 1998; Haregeweyn et al. 2008) yet only if concentrations of pesticides and herbicides are within acceptable ranges!!.

Sediment has also an impact on many (aquatic) ecological habitats on floodplains and within rivers and streams (Owens et al. 2005). Floodplains, for instance, are ecological habitats that are strongly influenced by sediment supply (Schertz 1983; Tockner et al. 2010). Sedimentation related to floods was found to delay or reduce the germination of some species of tree sapplings that normally grow in floodplains (Walls et al. 2005). Over the last two centuries dramatic "regime shifts" of these habitats have occured due to antropogenic impacts. This is certainly the case in southern Europe, were deforestation and its increase in sediment supply has lead to much more braided river systems in many regions (Tockner et al. 2010). Nevertheless, the actual trend in most Mediterranean mountains is to reduce braiding and increase incision, with vegetation expansion in the alluvial plains. (e.g., Beguería et al., 2006; Keesstra et al., 2005; Cosandey et al., 2005).

\section{Sediment Yield as a desertification indicator}

From the discussions above it is clear that desertification by water erosion should not only be assessed on the plot or hillslope scale, but that also the catchment sediment yield should be considered as this provides crucial additional information. As discussed in the introduction, only very few of the currently proposed desertification indicators related to soil erosion by water consider the catchment as a relevant functioning unit. Furthermore, these indicators are only rarely used in desertification assessments.

Of the indicators, listed in table 1, 'drainage density, flooding frequency and rainfall-runoff relationship' can be expected to have an important effect on the catchment SY. However, they are mainly related to the runoff characteristics of the catchment and are unable to provide specific information on the magnitude of SY. 'Floodplain and Channel Morphology' is directly influenced by SY and can be used to some extend as an integrated indicator of the physical impact of soil erosion within a catchment. However its use is also limited by the fact 
that floodplain and channel morphology are also influenced by other factors, such as tectonics, flow regime or changes in baselevel (Baker et al. 1988; Desertlinks 2004). Similarly, 'reservoir sedimentation' may provide important information about the extent of water erosion at the catchment scale, but it is also strongly influenced by the characteristics of the reservoir itself (e.g.: dimensions, trapping efficiency; Verstraeten \& Poesen 2000; figure 3 ) and is confined to catchments with reservoirs. Furthermore, no information on the use of reservoir sedimentation as a desertification indicator is available (Desertlinks 2004).

'Catchment sediment yield' could be a valid alternative desertification indicator to assess the state and impact of desertification by water erosion at the catchment scale. It is by definition the integrated result of all soil erosion and sediment deposition processes operating within the catchment. It also avoids most of the interpretation difficulties, related to other influencing factors, mentioned abvove.

Rubio \& Bochet (1998) provided a list of criteria which should be met by potential desertification indicators. Here we evaluate the potential to use 'catchment sediment yield' as a complementary desertification indicator, based on these criteria.

1. Reliable. An indicator should be reliable, scientifically valid and relatively indepent of sample size. This is the case for catchment sediment yield, as it is a clear and quantitative measure that is frequently used in many reports and scientific studies.

2. Biologically, policy and socially relevant. As discussed above (section III), SY has many important ecological and economical impacts that are relevant in the context of desertification. These impacts (such as reservoir sedimentation and damage to flood prevention infrastructure) are often ignored by on site indicators.

3. Measurable. Various procedures have been developed to measure SY. This is most commonly done by monitoring runoff discharge and sediment concentration at a gauging station, or by deriving it from the volume of sediments deposited in a reservoir or lake. An advantage of SY-estimates from reservoirs, is that they also include bedload. This type of sediment transport is rarely measured at gauging stations, although it can be very important, certainly in Mediterranean and mountainous regions (Verstraeten et al. 2006). A lot of literature is available on the accuracy, advantages and disadvantages of each of these procedures (e.g. Walling 1994; Verstraeten \& Poesen 2002; Verstraeten et al. 2006; Vanmaercke et al. subm.).

4. Sensitive to stressors. Numerous studies have illustrated and discussed how various anthropogenic or climatic stressors may have an impact on catchment SY (e.g. Walling \& Kleo 1979; Church \& Slaymaker 1989; Owens et al. 2005; Walling 2006; Garcia-Ruiz et 
al. 2010; Owens et al. 2010; Vanmaercke et al. 2010b). As discussed in a previous section, the response of catchment SY to disturbances can differ significantly over time and in magnitude from the response at the hillslope scale. Considering SY at the catchment scale therefore provides important additional information on the desertification process that can not be acquired when only the parcel or hillslope scale is considered. Also in mitigation strategies, SY can be an important factor to consider, because the reduction of hillslope erosion rates does not always lead to decreases in SY (see section II.2).

5. Cost effective. The costs of SY-measurements heavily depend on the method used, but can be high. Reliable SY measurements at a gauging station generally require a sufficiently long measuring period with a high sampling frequency and adequate equipment (Walling 1994; 2006). This is, however, also the case with some other indicators, such as soil loss at the plot scale. Estimating SY from the sedimentation rate of reservoir, lakes or ponds through bathymetric surveys may provide a cheaper alternative. Ponds and reservoirs are generally abundant, which makes it possible to study SY at a regional scale (Verstraeten et al. 2003; 2006). Furthermore, some tools are available to make estimates of SY, when no measurements are available. Semi-quantitative indicator models, for example, can be a useful to estimate the SY of ungauged catchments in a quick and inexpensive way. Such models generally use environmental factors to characterise a drainage basin in terms of sensitivity to erosion and sediment transport. They can include sheet-, rill-, gully, bank erosion, landslides, and connectivity, at least partly, in the assessment of basin SY. Their low data requirements and the fact that practically all significant erosion processes are considered makes them especially suited for estimating off-site effects of soil erosion (de Vente \& Poesen 2005).

6. Target level. Whereas a lot of research has been conducted on tolerable soil loss rates (e.g. Montgommery 2007; Verheijen et al. 2009), generally less attention has been given to target and tolerance levels of catchment SY (Owens et al. 2005). This partly illustrates the fact that the off site consequences of soil erosion have received relatively limited attention and are often underestimated (e.g. Schertz 1983; Poesen \& Hooke 1997; Haregeweyn et al. 2006). Setting target levels is complicated by the fact that baseline sediment yields values, i.e. the SY that could be expected if the catchment was not disturbed by human impacts, are generally unknown (e.g. Dearing et al. 2006). This is especially true for the Mediterranean region, as this area has a long history of human disturbances (e.g. Bintliff 2002; Hooke 2006). Furthermore, SY is generally considered to decrease with A (e.g. Walling 1983). However, analyses of large datasets of SY indicate 
that these decreases are generally limited or insignificant for various (semi-)arid regions (de Vente et al. 2007; Vanmaercke et al. subm.). Target levels can, eventually, also be defined for specific catchment areas, based on earlier calculated regional A-SY relationships. Furthermore, target levels for SY depend on the purpose or concern of the desertification study. If reservoir sedimentation is an issue, tolerable SY values will mainly depend on the life expectancy of the reservoir (generally 50-100 years). Based on this, an annual acceptable sedimentation rate can be calculated. Considering an average bulk density and the trapping effectiveness for sediments of the reservoir, this sedimentation rate can easily be converted to a target value of SY (e.g. Verstraeten \& Poesen 2002). For ecological issues, various target levels of nutrient, contaminant or suspended sediment concentrations have already been defined (for some examples and references, see e.g. Owens et al. 2005), depending on the risk type. When soil loss is the major concern, a first aproach could be to use the on site tolerable soil loss rate at the catchment scale. As discussed in section II.2, long and intense human occupation in the Mediterranean region, has often lead to thin and stony soils, which currently deliver only small volumes of sediments. Previously eroded sediments can, however, be stored as alluvial or colluvial deposits, which can be susceptible to gully or riverbank erosion. These erosion processes are not represented by plot scale measurements of soil erosion. Nevertheless, they can be very relevant, as these thick alluvial deposits are often the most productive soils of the catchments (e.g. Avni 2005). Confronting the SY with the tolerable soil loss rate can therefore provide a more valid assessment of the desertification status at the catchment scale.

Another approach could be to assess the regional variation in desertification, by comparing the SY of different catchments. Figure 2, for example, indicates that catchments in Mediterranean Europe have a median SY of around 200 ton $\mathrm{km}^{-2} \mathrm{yr}^{-1}$, while around $75 \%$ of the catchments has a SY below 500 ton $\mathrm{km}^{-2} \mathrm{yr}^{-1}$. Less than $10 \%$ of the catchments has a SY above 2000 ton $\mathrm{km}^{-2} \mathrm{yr}^{-1}$. SY values above 500 and especially above 2000 ton $\mathrm{km}^{-2} \mathrm{yr}^{-1}$ can already be an important indicator for desertification problems.

7. Assess present status. As discussed above, catchment SY can be used to assess a present desertification status, as it is the result of all ongoing soil erosion and sediment deposition processes in a catchment.

8. Assess trends over time. Catchment SY can be used to assess trends over time, by continuously measuring SY at a gauging station or by conducting multiple bathymetric surveys in a reservoir over different years (e.g. Walling 2006). Rivers in arid and semi- 
arid zones generally have runoff discharges and sediment yields that are highly sensitive to any changes in the headwaters, especially changes in vegetation cover (e.g. Walling \& Kleo 1979; Sharma 1998). The SY response of a catchment to disturbances can, however, be delayed. This is generally expressed as the response time. After this response time, a new average SY is reached, which is in equilibrium with the catchment characteristics (Owens et al. 2010). The response to catchment disturbances is often complex and difficult to predict, as this depends on specific conditions and tresholds, and as this is not necessarily linked to the responses at the hillslope scale. This underlines the importance of also considering trends in SY at the catchment scale for desertification assessments, as they offer another time perspective and as they are sensitive to other stressors than indicators at the plot scale (Imeson \& Lavee 1998).

9. Interpretable. A potential indicator should be easy to interpret and capable of distinguishing acceptable from unacceptable conditions in a scientifically and legally defensible way (Rubio \& Bochet 1998). The discussions above clearly illustrate that this is possible for catchment SY. Depending on the context, or the major concern, target values or maximum magnitude of change in SY can be established. A catchment SY or change above this value can serve as an important indicator for problematic conditions. Some caution is needed, however, in the interpretation of SY. A catchment SY below the target value does not necessarily indicate that there is no desertification problem. As discussed above, erosion hotspots can occur in a catchment without having an influence on the SY at the outlet. Moreover, reservoirs and ponds within the considered catchment may trap a part of the sediments, resulting in a lower SY. Sediment yield should therefore be used and interpreted as an indicator, in combination with other indicators (such as soil erosion at the plot scale). Also geomorphological maps can provide important additional information on the location of the major sediment sources (e.g. González et al. 1997). This avoids the risk of neglecting the major sediment sources of a catchment and allows to interprete trends of desertification over a longer time perspective. Most ideally sediment fluxes within a catchment and their temporal variability should be assessed by establishing comprehensive sediment budgets, considering all relevant sinks and sources. Such sediment budgets are, however, time-consuming, costly to develop and rarely available for (semi-)arid regions (Verstraeten et al. 2009; Trimble 2010). Catchment SY in combination with other erosion-related indicators can, however, provide a cheaper way to consider the most relevant erosion processes of a catchment. 
10. Readily available data. SY data are already widely available for many regions. As SY relates to various environmental and management issues (Owens et al. 2005), it is measured by various environmental agencies in several countries. Moreover, reservoirs and ponds are widely spread. For many of these, reservoir sedimentation rate data are available. Several reviews of available SY data have been made, for instance for Europe (Verstraeten et al. 2006; Vanmaercke et al. subm.), Northern Africa (Probst \& Amiotte Suchet 1992; Lahlou 1996), Africa in general (Walling 1984); the United States (Gray \& Gartner 2010; Gray et al. 2010) and Australia (Wasson et al. 1996).

\section{Conclusions}

Desertification indicators provide a useful mean to assess several aspects of desertification. For soil erosion by water, most of the currently used indicators are based on an on site assessment at the plot or hillslope scale. Little attention has been given to the state and impacts of soil erosion processes at the catchment scale. This study aimed to draw the attention to the fact that sediment yield at the catchment scale provides crucial additional information for desertification assessments. This requires more attention in indicator development, for example by the UNCCD.

SY can be several orders of magnitude larger than erosion rates at the plot scale, as these plots often not consider the most important sediment sources. Furthermore, the response of catchment SY to disturbances is generally complex and different from the response at the hillslope scale, as they can reflect the integrated result of various disturbances and land degradation processes of the past. Whereas these considerations are true for many catchments, they are especially valid for catchments in Mediterranean and (semi)-arid environments. SY at the catchment scale is also highly relevant to consider, as soil erosion can have many off-site impacts that are closely linked to desertifcation problems, such as reservoir sedimentation, flooding problems, the loss of fertile footslopes and floodplains, nutrient loss, eutrophication and the destruction of ecological habitats. Currently only very few studies exist that estimate the costs associated with these off-site consequences.

In an evaluation based on earlier established criteria, it was demonstrated that catchment sediment yield could be an effective desertification indicator. SY is a measurable, objective and relevant value that can be used to assess the desertification status of a catchment and has strong implications for multiple sectors of society. It allows the identification of other sediment sources than those considered at the plot scale and offers another time frame to 
assess desertification processes, as it responds to disturbances and control measures over longer time periods than the plot scale.

However, SY alone can not be used as a desertification indicator. SY is the aggregated result of all soil erosion and sediment deposition processes in the catchment, and does indicate which process is the major sediment source or where the dominant sediment sources are located. Moreover, SY can also underestimate ongoing erosion processes within the catchment, as eroded sediments may be redeposited before they reach the catchment outlet or the contribution of important sediment sources may be averaged out by large areas in the catchment that have little or no contribute to SY.

Therefore, SY should always be used in combination with other complementary information (such as erosion rates at the plot scale, geomorphic maps, ...). Only the combination of SY with such complementary information can reflect the full complexity of the soil erosion and sediment deposition processes at the catchment scale and their interactions with human activities. Furthermore, more research is needed to establish target and tolerance levels of catchment sediment yield under diverse environmental and geomorphological conditions, to take more advantage of SY as an indicator.

\section{Acknowledgments}

The research described in this paper was conducted within the framework of the EC-DG RTD- 6th Framework Research Programme (sub-priority 1.1.6.3) - Research on Desertification- project DESIRE (037046): Desertification Mitigation and Remediation of land - a global approach for local solutions. Dr. Nichola Geeson provided information on the DIS4ME indicator system. M. Vanmaercke received grant-aided support from the Research Foundation - Flanders (FWO), Belgium.

\section{References}

Avni, Y., 2005. Gully incision as a key factor in desertification in an arid environment, the Negev highlands, Israel. Catena 63: 185-220.

Baker V., Kochel R., Patton P., 1988. Flood Geomorphology, Wiley-Interscience, New York

Balasch, J. C., Castelltort, X., Llorens, P., Gallart, F., 1992. Hydrological and sediment dynamics network design in a Mediterranean mountainous area subject to gully erosion. In: Bogen, J., Walling, D., Day, T. (Editors), Erosion and Sediment Transport Monitoring Programes in River basins (Proceedings of a symposium held at Oslo, Norway, 24-28 August 1992). IAHS Publ. 210, IAHS, Wallingford, United Kingdom, pp. 423-432.

Basson, G., 2008. Reservoir Sedimentation - an overview of global sedimentation rates and predicted sediment deposition. Oral contribution to the international CHR Workshop - 
Expert Consultation: Erosion, Transport and Deposition of Sediments, Berne (28-30 April 2008), Switzerland, UNESCO, Book of Abstracts: pp. 74-79 + presentation.

Bazzofi, P., 1987. Previsione dellinterrimento nei serbatoi artificiali italiani, modello P.I.S.A., Idrotecnica 1: 15-18.

Beguería, S., López-Moreno, J.I., Gómez-Villar, A., Rubio, V., Lana-Renault, N., GarcíaRuiz, J.M., 2006. Fluvial adjustments to soil erosion and plant cover changes in the Central Spanish Pyrenees. Geografiska Annaler 88A(3): 177-186.

Bintliff, J., 2002. Time, process and catastrophism in the study of Mediterranean alluvial history: a review. World Archaeology, 33: 417-435.

Boix-Fayos, C., Barberá, G. G., López-Bermúdez, F., Castillo, V. M., 2007. Effects of check dams, reforestation and land-use changes on river channel morphology: Case study of the Rogativa catchment, Murcia, Spain. Geomorphology 91: 103-123.

Boix-Fayos, C., de Vente, J., Martínez-Mena, M., Barberá, G. G., Castillo, V., 2008. The impact of land use change and check-dams on catchment sediment yield, Hydrological Processes 22: 4922-4935.

Brandt J., Geeson N., Zucca C., 2006. Desertification indicator system for Mediterranean Europe (DIS4ME). In: Enne G., Yeroyanni M. (Eds.), Proceedings of the AID-CCD International Workshop: Local \& Regional Desertification Indicators in a Global Perspective. Beijing (16-18 May 2005), China, pp. 43-58.

Cammeraat, L. H., 2002. A review of two strongly contrasting geomorphological system within the context of scale, Earth Surface Processes and Landforms 27: 1201-1222.

Cammeraat, E., 2004. Scale dependent thresholds in hydrological and erosion response of a semi-arid catchment in southeast Spain. Agriculture, Ecosystems and Environment 104: 317-332.

Church, M. and Slaymaker, O. (1989). Holocene disequilibrium of sediment yield in British Columbia. Nature 327, 452-454.

Clapp, E., Bierman, P., Schick, A., Lekach, J., Enzel, Y., Caffee, M., 2000. Sediment yield exceeds sediment production in arid region drainage basins. Geology 28: 995-998.

Cosandey, C., Andréassian, V., Martin, C., Didon-Lescot, J.F., Lavabre, J., Folton, N., Mathys, N., Richard, D., 2005. The hydrological impact of the Mediterranean forest: a review of French research. Journal of Hydrology 301: 235-249.

Dearing, J., Battarbee, R., Dikau, R., Larocque, I., Oldfield, F., 2006. Human-environment interactions: learning from the past. Regional Environmental Change 6: 1-16.

DESERTLINKS, 2004. Desertification Indicator System for Mediterranean Europe (DIS4ME). European Commission, Contract EVK2-CT-2001-00109, http://www.kcl.ac.uk/projects/desertlinks/ (last accessed: 23 July 2010)

DESERTNET, 2008. Monitoring and actions to Combat Desertification in Mediterranean Europe. http://smap.ew.eea.europa.eu/fol120392/prj957150/ (last accessed: 23 July 2010)

DESIRE, 2010. Desertification Mitigation and Remediation of land - a global approach for local solutions. EC-DG RTD- 6th Framework Research Programme (037046). http://www.desire-project.eu/ (last accessed: 23 July 2010)

de Vente, J., Poesen, J., 2005. Predicting soil erosion and sediment yield at the basin scale: Scale issues and semi-quantitative models, Earth-Science Reviews 71: 95-125.

de Vente, J., Poesen, J., Arabkhedri, M., Verstraeten, G., 2007. The sediment delivery problem revisited, Progress in Physical Geography 31: 155-178.

de Vente, J., Poesen, J., Verstraeten, G., Vanrompaey, A., Govers, G., 2008. Spatially distributed modelling of soil erosion and sediment yield at regional scales in Spain. Global and Planetary Change 60: 393-415. 
de Wit, M., Stankiewicz, J., 2006. Changes in Surface Water Supply Across Africa with Predicted Climate Change. Science 311: 1917-1921.

Douglas, I., 1967. Man, Vegetation and the Sediment Yield of rivers. Nature 215: 925-928.

Duijsings, J. J. H. M., 1986. Seasonal variation in the sediment delivery ratio of a forested drainage basin in Luxembourg. In: Hadley, R. (Editor), Drainage basin delivery (Proceeding of a symposium held in Albuquerque, New Mexico, USA, 4-8 August 1986), IAHS Publ. 159, IAHS, Wallingford, United Kingdom, pp. 153-164.

FAO-LADA, 2010. Land Degradation Assessment in Drylands. http://www.fao.org/nr/lada/ (last accessed: 23 July 2010)

Fonseca, R., Barriga, F., Fyfe, W., 1998. Reversing desertification by using dam reservoir sediments as agriculture soils. Episodes 21: 218-224.

García-Ruiz, J. M., Lana-Renault, N., Beguería, S., Lasanta, T., Regüés, D., Nadal-Romero, E., Serrano-Muela, P., López-Moreno, J. I., Alvera, B., Martí-Bono, C., Alatorre, L. C., 2010. From plot to regional scales: Interactions of slope and catchment hydrological and geomorphic processes in the Spanish Pyrenees, Geomorphology 120: 248-257.

González, C., García-Ruiz, J.M., Martí, C., White, S., Errea, M.P., Arnáez, J., 1997. Sediment sources in a Small, Abandoned Farmland Catchment, Central Spannish Pyrenees. Physics and Chemistry of the Earth 22: 291-293.

Govers, G., Van Oost, K. and Poesen, J., 2006. Responses of a semi-arid landscape to human disturbance: A simulation study of the interaction between rock fragment cover, soil erosion and land use change. Geoderma 133: 19-31.

Gray, J., Gartner, J., 2010. Overview of selected surrogate technologies for high-temporal resolution suspended sediment monitoring. Proceedings of the 2nd Joint Federal Interagency Conference (June 27 - July 1, 2010), Las Vegas, NV, pp. 207.

Gray, J., Stewart, D., McFaul, E., Laurent, K., Schwarz, G., Bernard, J., Stinson, J., Jonas, M., Webb, J., Randle, T., 2010. Development of a national, dynamic reservoir sedimentation database. Proceedings of the 2nd Joint Federal Interagency Conference (June 27 - July 1, 2010), Las Vegas, NV, pp. 172.

Haregeweyn, N., Poesen, J., Nyssen, J., De Wit, J., Haile, M., Govers, G., Deckers, S., 2006. Reservoirs in Tigray (northern Ethiopia): characteristics and sediment deposition problems. Land degradation and development 17: 211-230.

Haregeweyn, N., Poesen, J., Deckers, J., Nyssen, J., Mitiku Haile, Govers, G., Verstraeten, G., Moeyersons, J. 2008. Sediment-bound nutrient export from micro-dam catchments in Northern Ethiopia. Land Degradation and Development 19: 136 - 152.

Hein, L., 2007. Assessing the costs of land degradation: a case study for the Puentes catchment, Southeast Spain. Land Degradation \& Development 18: 631-642.

Hooke, J., 2006. Human impacts on fluvial systems in the Mediterranean region, Geomorphology 79: 311-335.

Imeson, A., Lavee, H., 1998. Soil erosion and climate change: the transect approach and the influence of scale. Geomorphology 23: 219-227.

Keesstra, S.D., Van Huissteden, J., Vandenberghe, J., Van Dam, O., De Gier, J., Pleizier, I.D., 2005. Evolution of the morphology of the river Dragonja (SW Slovenia) due to landuse changes. Geomorphology 69: 191-207.

Kirkby, M.J., Jones, R.J.A., Irvine, B., Gobin, A., Govers, G., Cerdan, O., Van Rompaey, A.J.J., Le Bissonnais, Y., Daroussin, J., King, D., Montanarella, L., Grimm, M., Vieillefont, V., Puigdefabregas, J., Boer, M., Kosmas, C., Yassoglou, N., Tsara, M., Mantel, S., Van Lynden, G., 2004. Pan-European Soil Erosion Risk Assessment: The PESERA Map, Version 1 October 2003. Explanation of Special Publication. No.73 
(S.P.I.04.73). European Soil Bureau Research Report No.16, EUR 21176, Office for Official Publications of the European Communities, Luxembourg.

Kirkby, M., Irvine, B.J., Jones, R., Govers, G., the PESERA team, 2008. The PESERA coarse scale erosion model for Europe. I. - Model rationale and implementation.European Journal of Soil Science 59: 1293-1306.

Kosmas C., Kirkby M., Geeson N., 1999. The MEDALUS project. Mediterranean Desertification and Land Use. Manual on key indicators of desertification and mapping environmentally sensitive areas to desertification. European Commission, Brussels

Kosmas C., Tsara M., Moustakas N., Karavitis, C., 2003. Land desertification and identification indicators. Annals in Arid Zones 393-416.

Kuhlman, T., Reinhard, S., Gaaf, A., 2010. Estimating the costs and benefits of soil conservation in Europe. Land Use Policy 27: 22-32.

Lahlou, A., 1996. Environmental and socio-economic impacts of erosion and sedimentation in north Africa. In: Walling, D., Webb, B. (Eds.), Erosion and sediment yield: global and regional perspectives, IAHS Publ. 236, IAHS, Wallingford, United Kingdom, pp. 491500 .

Lasanta, T., Beguería, S., García-Ruiz, J., 2006. Geomorphic and hydrological effects of traditional shifting agriculture in a Mediterranean mountain, Central Spanish Pyrenees, Mountain Research and Development 26: 146-152.

López-Bermúdez, F., 1990. Soil erosion by water on the desertification of a semi-arid Mediterranean fluvial basin: the Segura basin, Spain. Agriculture, Ecosystems \& Environment 33: 129-145.

LUCINDA, 2008. Land Care In Desertification Affected Areas: from science towards application. EU Sixth Framework Program, project reference: 18347. http://geografia.fcsh.unl.pt/lucinda/ (last accessed: 23 July 2010)

Maetens, W.; Poesen, J., V. M.; Jankauskas, B. \& Jankauskiene, G., 2010. Effects of soil and water conservation on runoff and soil loss by sheet and rill erosion in the EuroMediterranean region, Earth-Science Reviews (in preparation).

Maetens, W., Vanmaercke, M. \& Poesen, J., 2009. Assessment of the effectiveness of soil and water conservation measures in reducing runoff and soil loss: establishment of a European database, in: Advances in studies on desertification. Contributions to the international conference on desertification in memory of Professor John B. Thornes, Murcia 2009 (Ed. by A. Romero Diaz, F. Belmonte Serrato, F. Alonso Sarria \& F. López Bermúdez), ICOD , 303-306.

Martínez-Carreras, N., Udelhoven, T., Krein, A., Gallart, F., Iffly, J. F., Ziebel, J. F., Hoffmann, L., Pfister, L., Walling, D. E., 2010. The use of sediment colour measured by diffuse reflectance spectrometry to determine sediment sources: Application to the Attert River catchment, Luxembourg. Journal of Hydrology 382: 49-63.

Metzger, M. J., Bunce, R. G. H, Jongman, R. H. G, Mücher, C. A. \& Watkins, J. W., 2005. A climatic stratification of the environment of Europe. Global Ecol. Biogeogr. 14, 549563.

Montgommery, D., 2007. Soil erosion and agricultural sustainability. PNAS 104: 1326813272.

Morris, G. L., Annandale, G., Hotchkiss, R., 2008. Reservoir Sedimentation. In: Garcia, M. H. (Ed.), Sedimentation Engineering: processes, measurements, modeling, and Practice, ASCE, Reston, Viriginia, pp. 579-612.

Mücher, C. A., Wascher, D. M., Klijn, J. A., Koomen, A. J. M.\& Jongman, R. H. G., 2006. A new European Landscape Map as an integrative framework for landscape character assessment. In: Landscape Ecology in the Mediterranean: inside and outside 
approaches (ed. by R. G. H. Bunceand \& R. H. G. Jongman) (Proc. European IALE Conference 29 March-2 April 2005, Faro, Portugal), 233-243. IALE Publication Series 3.

Nadal-Romero, E., Regüés, D., Latron, J., Lana-Renault, N., Serrano-Muela, P., Martí-Bono, C., 2007. Badland areas: the main suspended sediment source in Central Spanish Pyrenees. Proceedings of the COST 634 International Conference on off-site impacts of soil erosion and sediment transport (1-3 October 2007). Czech Technical University in Prague, Faculty of Civil Engineering, Department of Drainage, Irrigation and Landscape Engineering, Prague, Czech Republic, pp.115-123.

Nadal-Romero, E., Martínez-Murillo, J.-F., Vanmaercke, M., Poesen, J., accepted. Scaledependency of sediment yield from badland areas in Mediterranean 1 environments. Progress in Physical Geography: under revision.

Nyssen, J., Poesen, J., Moeyersons, J., Deckers, J., Haile, M., Lang, A., 2004. Human impact on the environment in the Ethiopian and Eritrean highlands-a state of the art. EarthScience Reviews 64: 273-320.

Nyssen J., Poesen J., Descheemaeker K., Haregeweyn N., Haile M., Moeyersons J., Frankl A., Govers G., Munro N., Deckers J., 2008. Effects of region-wide soil and water conservation in semi-arid areas: the case of northern Ethiopia. Zeitschrift für Geomorphologie 52:291-315.

Oldeman, L.R., Hakkeling, R.T.A., Sombroek, W.G., 1991. World map of the status of human induced soil degradation. UNEP/ISRIC Glasod Project, Nairobi/Wageningen.

Olivry, J. C., Hoorelbeck, J., 1989. Erodibilité des terres noires de la vallée du Buëch, France, Alpes du Sud. ORSTOM 25: 95-110 (in French).

Owens, P. N., Batalla, R. J., Collins, A. J., Gomez, B., Hicks, D. M., Horowitz, A. J., Kondolf, G. M., Marden, M., Page, M. J., Peacock, D. H., Petticrew, E. L., Salomons, W., Trustrum, N. A., 2005. Fine-grained sediment in River Systems: environmental significance and management issues. River Research and Applications 21: 693-717.

Owens, P., Petticrew, E., van der Perk, M., 2010. Sediment response to catchment disturbances. Journal of Soils and Sediments 10: 591-596.

Palmieri, A., Shah, F., Dinar, A., 2001. Economics of reservoir sedimentation and sustainable management of dams. Journal of Environmental Management 61: 149-163.

Pimentel, D., Harvey, C., Resosudarmo, P., Sinclair, K., Kurz, D., McNair, M., Crist, S., Shpritz, L., Fitton, L., Saffouri, R., Blair, R., 1995. Environmental and Economic Costs of Soil Erosion and Conservation Benefits. Science 267: 1117-1123.

Plata Bedmar, A., Cobo Rayan, R., Sanz Montero, E., Gómez Montaña, J.L., Avendaño Salas, C., 1997. Influence of the Puentes reservoir operation procedure on the sediment accumulation rate between 1954-1994. In: Commission Internationale des Grands Barrages (Ed.), Proc. 19th Congress Grands Barrages, Florence, Italy, pp. 835-847.

Poesen, J., 1995. Soil erosion in Mediterranean environments. In: Fantechi, R., Peter, D., Balabanis, P. \& Rubio, J.L. (Eds.), Desertification in a European Context: physical and socioeconomic aspects, Proceedings of the European School of Climatology and Natural Hazards Course, El Campello, Pueblo Acantilado, Alicante, Spain, 6-13 October 1993, EUR 15414 EN. Luxembourg: Office for Official Publications of the European Communities, pp. 123-152.

Poesen, J., Hooke, J., 1997. Erosion, flooding and channel management in Mediterranean environments of southern Europe. Progress in Physical Geography 21: 157-199.

Poesen, J., Nachtergaele, J., Verstraeten, G., Valentin, C., 2003. Gully erosion and environmental change: importance and research needs. Catena 50: 91- 133. 
Poesen, J., Torri, D.\& Bunte, K., 1994. Effects of rock fragments on soil erosion by water at different spatial scales: a review. Catena 23: 141-166.

Porto, P., Walling, D. E., Callegari, G., 2004. Validating the use of Caesium-137 measurements to estimate erosion rates in three small catchments in Southern Italy. In: Golosov, V., Belyaev, V., Walling, D. (Editors), Sediment Transfer through the Fluvial System (Proceedings of the Moscow Symposium, August 2004). IAHS Publ. 288, IAHS, Wallingford, United Kingdom, pp. 78-83.

Probst, J., Amiotte Suchet, P., 1992. Fluvial suspended sediment transport and mechanical erosion in the Maghreb (North Africa). Hydrological Sciences Journal 37: 621-637.

Robinson, A., 1977. Relationship between soil erosion and sediment delivery. In: Erosion and Solid Matter Transport in Inland Waters, Proceedings of a symposium held at Paris, July 1977, IAHS, pp. 159-167.

Roquero, E., 1991. Le barrage de Nijar ou d'Isabell II (Almeria, Espagne), une étude de l'influence de la géomorphologie sur l'accéleration de l'ensablement. Zeitschrift für geomorphologie Supplement band 83: 9-16

Rubio, J., Bochet, E., 1998. Desertification indicators as diagnosis criteria for desertification risk assessment in Europe. Journal of Arid Environments 39:113-120.

Salvador Sanchis, M.P., Torri, D., Borselli, L., Poesen, J., 2008. Climate effects on soil erodibility. Earth Surface Processes and Landforms 33: 1082-1097.

Schertz, D.L., 1983. The basis for soil loss tolerances. Journal of Soil and Water Conservation 38: $10-14$.

Schick, A., Grodek, T., Lekach, J., 1997. Sediment management and flood protection of desert towns: effects of small catchments. In: Walling, D., Probst, J.-L. (Eds.), Human Impact on Erosion \& Sedimentation (Proceedings of Rabat Symposium S6, April 1997), IAHS Publ. 245, pp. 183-189.

Schumm, S.A., Mosley, M.P. and Zimpfer, G.L., 1976. Unsteady state denudation. Science, 191: 871.

Sharma, K., 1998. The hydrological indicators of desertification. Journal of Arid Environments 39: 121-132.

Sisák, I., Máté, F., Szücs, P., 2007. Sediment and phosphorous loads from three small catchments in the watershed of Lake Balaton. Proceedings of the COST 634 International Conference on off-site impacts of soil erosion and sediment transport (13 October 2007). Czech Technical University in Prague, Faculty of Civil Engineering, Department of Drainage, Irrigation and Landscape Engineering, Prague, Czech Republic, pp. 54.

Small, I. F., Rowan, J. S., Duck, R. W., 2003. Long-term sediment yield in Crombie Reservoir catchment, Angus, and its regional significance within the Midland Valley of Scotland. Hydrological Sciences 48: 619-635.

Sogon, S., Penven, M., Bonte, P., Muxart, T., 1999. Estimation of sediment yield ans soil loss using suspended sediment load and 137Cs measurements on agricultural land, Brie Plateau, France. Hydrobiologia 410: 251-261.

Tockner, K., Pusch, M., Bochardt, D., Lorang, M., 2010. Multiple stressors in coupled riverfloodplain ecosystems. Freshwater Biology 55 (Suppl. 1): 135-151.

Trimble W., 2010. Streams, valleys and floodplains in the sediment cascade. In: Burt, T., Allison, R. (eds.), Sediment Cascades. An integrated approach, Willey-Blackwell, Chichester, United Kingdom, pp. 307-344.

UNCCD, 2010. Meeting on methodologies and data needs for the sub-set of UNCCD impact indicators: landcover status and proportion of the population in affected areas living above the poverty line. Report, available online: http://www.unccd.int/science/ 
announce/meeting-on-methodologies-data-needs.php (last accessed: 8 September 2010)

UNEP, 1994. United Nations Convention to Combat Desertification in those countries experiencing serious drought and/or desertification, particularly in Africa. Text with annexes. Geneva: United Nations Environment Programme for the Convention to Combat Desertification (CCD), Interim Secretariat for the CCD. $71 \mathrm{pp}$.

Vandekerckhove, L., Poesen, J., Oostwoud Wijdenes, D., Nachtergaele, J., Kosmas, C., Roxo, M., De Figueiredo, T., 2000. Thresholds for gully initiation and sedimentation in Mediterranean Europe. Earth Surface Processes and Landforms 25: 1201-1220.

Van Dijk, P. M., Kwaad, F. J. P. M., 1996. Runoff Generation and Soil Erosion in Small Agricultural catchments with loess-derived soils. Hydrological Processes 10: 10491059.

Vanmaercke M., Poesen J. Verstraeten G., Maetens W., de Vente J., Ocakoglu F., 2010a. Sediment yield in Europe: regional differences in scale dependence. In: Banasik K., Horowitz A., Owens P., Stone M., Walling D. (Eds.) Sediment dynamics for a changing Future (Proceedings of the ICCE symposium held at Warsaw University of Life Sciences - SGGW, Poland 14-18 June 2010). IAHS Publ. 337, pp. 44-52.

Vanmaercke, M., Zenebe, A., Poesen, J., Nyssen, J., Verstraeten, G., Deckers, J., 2010b. Sediment dynamics and the role of flash floods in sediment export from medium-sized catchments: a case study from the semi-arid tropical highlands in northern Ethiopia. Journal of Soils and sediments 10: 611-627.

Vanmaercke, M., Poesen, J., Verstraeten, G., de Vente, J., Maetens, W., Ocakoglu, F., submitted. Sediment yield in Europe: spatial patterns and scale dependency. Geomorphology: under revision.

Van Rompaey, A.J.J., Vieillefont, V., Jones, R.J.A., Montanarella, L., Verstraeten, G, Bazzoffi, P., Dostal, T, Krasa, J, de Vente, J., Poesen, J., 2003. Validation of soil erosion estimates at European scale. European Soil Bureau Research Report No.13, EUR 20827 EN, 26pp. Office for Official Publications of the European Communities, Luxembourg.

Verheijen, F., Jones, R., Rickson, R., Smith, C., 2009. Tolerable versus actual soil erosion rates in Europe. Earth-Science Reviews 94: 23-38.

Verstraeten, G., Lang, A., Houben, P., 2009. Human impact on sediment dynamics quantification and timing. Catena 77: 77-80.

Verstraeten, G., Poesen, J., 2000. Estimating trap efficiency of small reservoirs and ponds: methods and implications for the assessment of sediment yield. Progress in Physical Geography 24: 219-251.

Verstraeten, G., Poesen, J., 2001. Factors controlling sediment yield from small intensively cultivated catchments in a temperate humid climate. Geomorphology 40: 123-144.

Verstraeten, G., Poesen, J., 2002. Using sediment deposits in small ponds to quantify sediment yield from small catchments: possibilities \& limitations. Earth Surface Processes and Landforms 27: 1425-1439.

Verstraeten, G., Bazzoffi, P., Lajczak, A., Radoane, M., Rey, F., Poesen, J., de Vente, J., 2006. Reservoir and Pond Sedimentation in Europe In: Boardman, J., Poesen, J. (Editors), Soil Erosion in Europe, John Wiley \& Sons Ltd., Chichester, United Kingdom, pp. 759-774.

Vörösmarty, C., Meybeck, M., Fekete, B., Sharma, K., Green, P., Syvitski, J. 2003. Anthropogenic sediment retention: major global impact from registered river impoundments. Global and Planetary Change 39: 169-190.

Walling, D., 1983. The sediment delivery problem. Journal of Hydrology 65: 209-237. 
Walling, D., 1984. The sediment yield of African rivers. In: Walling, D., Foster, S., Wurzel, P. (Eds.), Challenges in African Hydrology and Water Resources, Proceedings of the Harare symposium, IAHS Publ. 144, pp. 265-283.

Walling, D., 1994. Measuring Sediment Yield From River Basins. In: Lal, R. (Ed.), Soil Erosion Research Methods, Winrock International, Arlington, Virginia, pp. 39-73.

Walling, D. E., 2006. Human impact on land-ocean sediment transfer by the worlds rivers. Geomorphology 79: 192-216.

Walling, D., Kleo, A., 1979. Sediment yields of rivers in areas of low precipitation: a global view. In: Hydrology of Areas of Low Precipitation, Proceedings of a symposium held during the XVII Assembly of the International Union of Geodesy and Geophysics at Canberra, December 1979. pp. 479-493.

Walls, R., Wardrop, D., Brooks. R., 2005. The impact of experimental sedimentation and flooding on the growth and germination of floodplain trees. Plant Ecology 176:203213.

Wasson, B., Olive, L., Rosewell, C., 1996. Rates of Erosion and sediment transport in Australia. In: Walling, D., Webb, B. (Eds.), Erosion and sediment yield: global and regional perspectives, IAHS Publ. 236, IAHS, Wallingford, United Kingdom, pp. 139148.

White, R., 2001. Evacuation of sediments from reservoirs, Thomas Telford Publishing, London, United Kingdom, 280 pp.

Yu, L., Oldfield, F., 1993. Quantitative sediment source ascription using magnetic measurements in a reservoir-catchment system near Nijar, S.E. Spain. Earth Surface Processes and Landforms 18: 441-454. 


\section{TABLES}

Table 1: List of 71 desertification indicators that are related to water erosion, proposed in the DIS4ME-dabase (Desertlinks, 2004). For indicators in italic no detailed description is available. Indicators in bold can be considered to reflect the integrated result of processes at the catchment scale.

\begin{tabular}{|c|c|}
\hline Physical \& Ecological Indicators & Economic Indicators \\
\hline Climate & Land Management \\
\hline 1 Rainfall & 45 Agri-environmental management \\
\hline 2 Rainfall erosivity & 46 Management quality index \\
\hline Runoff & 47 Organic farming \\
\hline 3 Dam sedimentation & 48 Reclamation of affected soils \\
\hline 4 Drainage density & 49 Reclamation of mining areas \\
\hline 5 Erosivity & 50 Soil erosion control measures \\
\hline 6 Flooding frequency & 51 Soil water conservation measures \\
\hline 7 Floodplain and channel morphology & 52 Sustainable farming \\
\hline 8 Impervious surface area & 53 Terraces (presence of) \\
\hline 9 Rainfall-runoff relationship & Land use \\
\hline 10 Runoff threshold & 54 Area of cultivated \& semi-natural vegetation \\
\hline 11 Soil permeability & 55 Area of marginal soil used \\
\hline Soils & 56 Land abandoned from agriculture \\
\hline 12 Drainage & 57 Land use evolution \\
\hline 13 Erosion risk (RDI) & 58 Land use intensity \\
\hline 14 Infiltration capacity & 59 Land use type \\
\hline 15 Organic matter in surface soil rs & 60 Natural vegetation \\
\hline 16 Organic matter in surface soil & Cultivation \\
\hline 17 Organic matter mixing with depth & 61 Area of hillslope cultivated \\
\hline 18 Parent material & 62 Tillage direction \\
\hline 19 Rock fragments & 63 Tillage depth \\
\hline 20 Slope aspect & 64 Tillage operations \\
\hline 21 Slope gradient & Husbandry \\
\hline 22 Soil crusting & 65 Grazing \\
\hline 23 Soil depth & 66 Grazing control \\
\hline 24 Soil erosion (USLE) & 67 Grazing impact \\
\hline 25 Soil erosion (measured) & 68 Grazing intensity \\
\hline 26 Soil loss index & 69 Husbandry intensity \\
\hline 27 Soil quality index & Water use \\
\hline 28 Soil stability index & 70 Hydrological regulation (artificial) \\
\hline 29 Soil structure & 71 Runoff water storage \\
\hline \multicolumn{2}{|l|}{30 Soil surface stability } \\
\hline \multicolumn{2}{|l|}{31 Soil texture } \\
\hline \multicolumn{2}{|l|}{32 Soil type } \\
\hline \multicolumn{2}{|l|}{33 Water storage capacity } \\
\hline \multicolumn{2}{|l|}{ Vegetation } \\
\hline \multicolumn{2}{|l|}{34 Area of matorral } \\
\hline \multicolumn{2}{|l|}{35 Deforested area } \\
\hline \multicolumn{2}{|l|}{36 Erosion protection } \\
\hline \multicolumn{2}{|l|}{37 Vegetation cover } \\
\hline \multicolumn{2}{|l|}{38 Vegetation cover rs } \\
\hline \multicolumn{2}{|l|}{39 Vegetation cover type } \\
\hline \multicolumn{2}{|l|}{40 Vegetation quality index } \\
\hline \multicolumn{2}{|l|}{ Fire } \\
\hline \multicolumn{2}{|l|}{41 Burned Area } \\
\hline \multicolumn{2}{|l|}{42 Fire Frequency } \\
\hline \multicolumn{2}{|l|}{43 Forest and wild fires } \\
\hline 44 Wild fire incidence & \\
\hline
\end{tabular}


Table 2: Description of the catchments, with drainage areas $\leq 1 \mathrm{~km}^{2}$, for which both PESERA predicted soil loss rates and measured sediment yield are available, see figure 1 .

\begin{tabular}{|c|c|c|c|c|c|}
\hline Catchment & Country & $\mathrm{A}\left(\mathrm{km}^{2}\right)$ & Dominant Land Use & Dominant Lithology & Source \\
\hline \multicolumn{6}{|c|}{ NON-MEDITERRANEAN } \\
\hline Ville-en-Hesbaye (Braives) & BEL & 1.03 & Cropland & Loess & Verstraeten \& Poesen 2001 \\
\hline Hammeveld 1 (Bertem) & BEL & 0.29 & Cropland & Loess & Verstraeten \& Poesen 2001 \\
\hline Hannut & BEL & 0.73 & Cropland & Loess & Verstraeten \& Poesen 2001 \\
\hline Nerm (Hoegaarden) & BEL & 0.20 & Cropland & Loess & Verstraeten \& Poesen 2001 \\
\hline Sterrebeek (Zaventem) & BEL & 0.07 & Cropland & Loess & Verstraeten \& Poesen 2001 \\
\hline Vannetin (D-Leudon) & FRA & 0.06 & Cropland & Clayey silty soils & Sogon et al. 1999 \\
\hline Pinmacher & GBR & 0.43 & $\begin{array}{l}\text { Rough grazing } \\
\text { moorland }\end{array}$ & $\begin{array}{c}\text { M. Ordovician sediments and igneous } \\
\text { rocks }\end{array}$ & Small et al. 2003 \\
\hline Nagyhorváti & HUN & 0.77 & Cropland & Sandy loess & Sisak et al. 2007 (+ Pers. Comm.) \\
\hline Schrondweilerbaach & LUX & 0.61 & $\begin{array}{l}\text { Oak, hornbeam \& } \\
\text { beech forest }\end{array}$ & Triasic Marls & Duijsings 1986; Cammeraat 2002 \\
\hline Weierbach & LUX & 0.40 & Forest & Schist & Martinez-Carreras et al. 2010 \\
\hline Etzenrade-2 & NLD & 0.09 & Cropland & Loess & Van Dijk \& Kwaad 1996 \\
\hline Catsop-2 & NLD & 0.06 & Cropland & Loess & VanDijk \& Kwaad 1996 \\
\hline St Gillisstraat-2 & NLD & 0.05 & Cropland & Loess & VanDijk \& Kwaad 1996 \\
\hline \multicolumn{6}{|c|}{ MEDITERRANEAN } \\
\hline Cal Parisa & ESP & 0.17 & $\begin{array}{c}\text { Abandoned } \\
\text { agricultural terraces }\end{array}$ & $\begin{array}{c}\text { Mesozoic continental mudrock \& } \\
\text { limestone beds }\end{array}$ & Balasch et al. 1992 \\
\hline Cantarrales 2 & ESP & 0.36 & Forest & Marls \& limestone & Boix-Fayos et al. 2007; 2008 \\
\hline Escribano & ESP & 0.08 & $\begin{array}{l}\text { Forest \& dry land } \\
\text { agriculture }\end{array}$ & Marls \& limestone & Boix-Fayos et al. 2007; 2008 \\
\hline Javanas & ESP & 0.11 & Shrubland \& forest & Marls \& limestone & Boix-Fayos et al. 2007; 2008 \\
\hline Loma Parrilla & ESP & 0.17 & Forest & Marls \& limestone & Boix-Fayos et al. 2007; 2008 \\
\hline Salvalejo & ESP & 0.19 & Forest & Marls \& limestone & Boix-Fayos et al. 2007; 2008 \\
\hline Suerte Estrecha & ESP & 0.49 & Forest & Marls \& limestone & Boix-Fayos et al. 2007; 2008 \\
\hline Araguás & ESP & 0.45 & $\begin{array}{l}\text { forest, grassland, } \\
\text { shrubland \& } \\
\text { badlands }\end{array}$ & Eocene marls \& flysch & Nadal Romero et al. 2007 \\
\hline Vallée du Buëch (St Genis) & FRA & 0.02 & badlands & Black marls & Olivry \& Hoorelbeck 1989 \\
\hline Cavalcanti & ITA & 0.62 & arable land* & Crystalline rocks and migmatites $*$ & Bazoffi 1987 \\
\hline Ponte Valleceppi & ITA & 0.46 & arable land* & River alluvium* & Bazoffi 1987 \\
\hline Ramazzano & ITA & 0.32 & arable land* & Calcereous rocks* & Bazoffi 1987 \\
\hline Crepacuore & ITA & 0.02 & Eucalyptus trees & $\begin{array}{l}\text { Upper Pliocene \& Quaternary clays, } \\
\text { sandy clays and sands }\end{array}$ & Porto et al. 2004 \\
\hline
\end{tabular}

* Dominant land use and lithology were derived from the LANMAP2 European Landscape Classification Map (Mücher et al. 2006) as this information was not reported in the original publication 


\section{FIGURES}

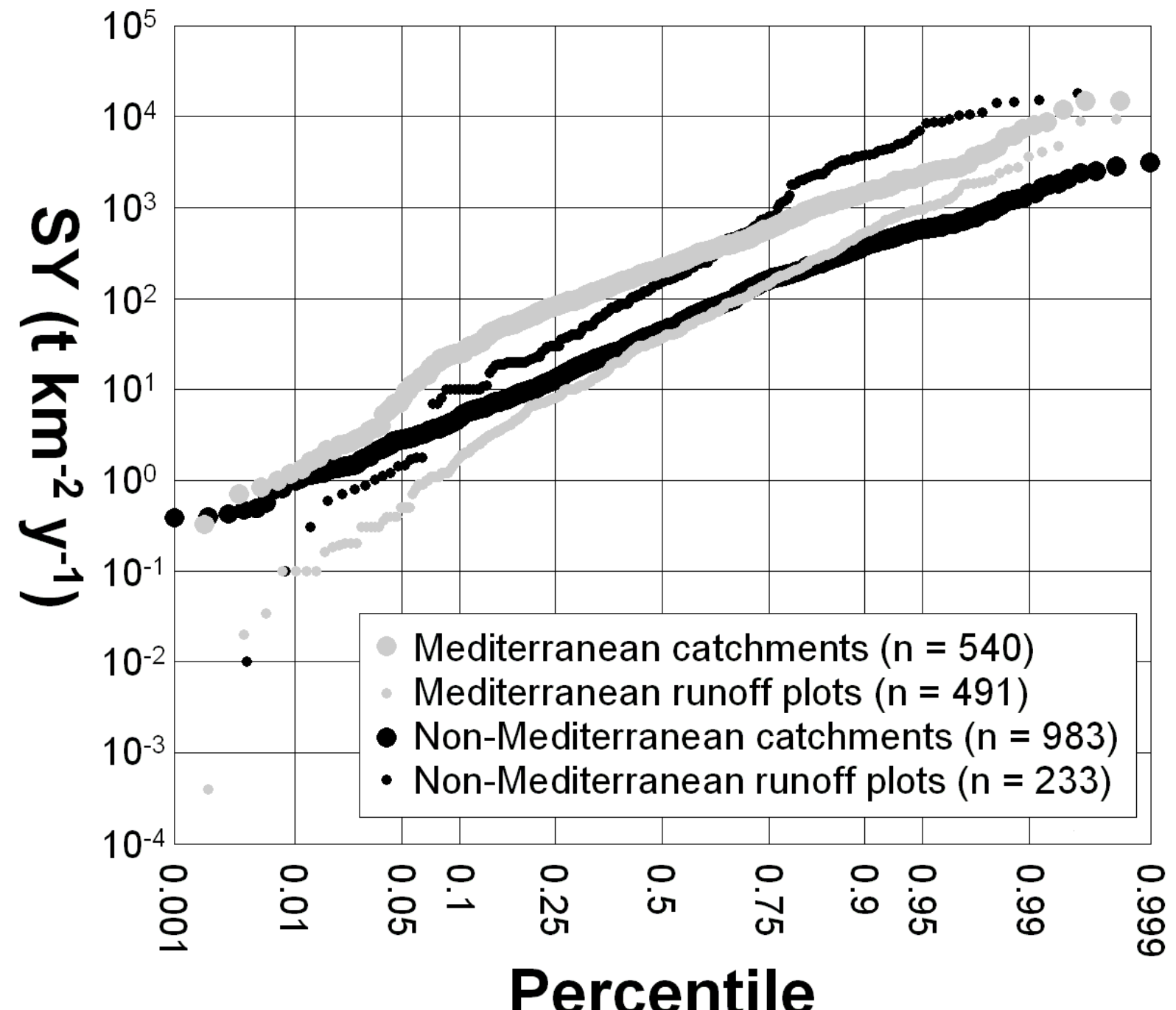

Figure 1: Cumulative frequency distribution of catchment SY-values and plot soil loss rates for Europe. The non-Mediterranean data contain data from the Atlantic, Boreal and Continental climatic zone (for details on the data used, see Vanmaercke et al. 2010; subm.) 


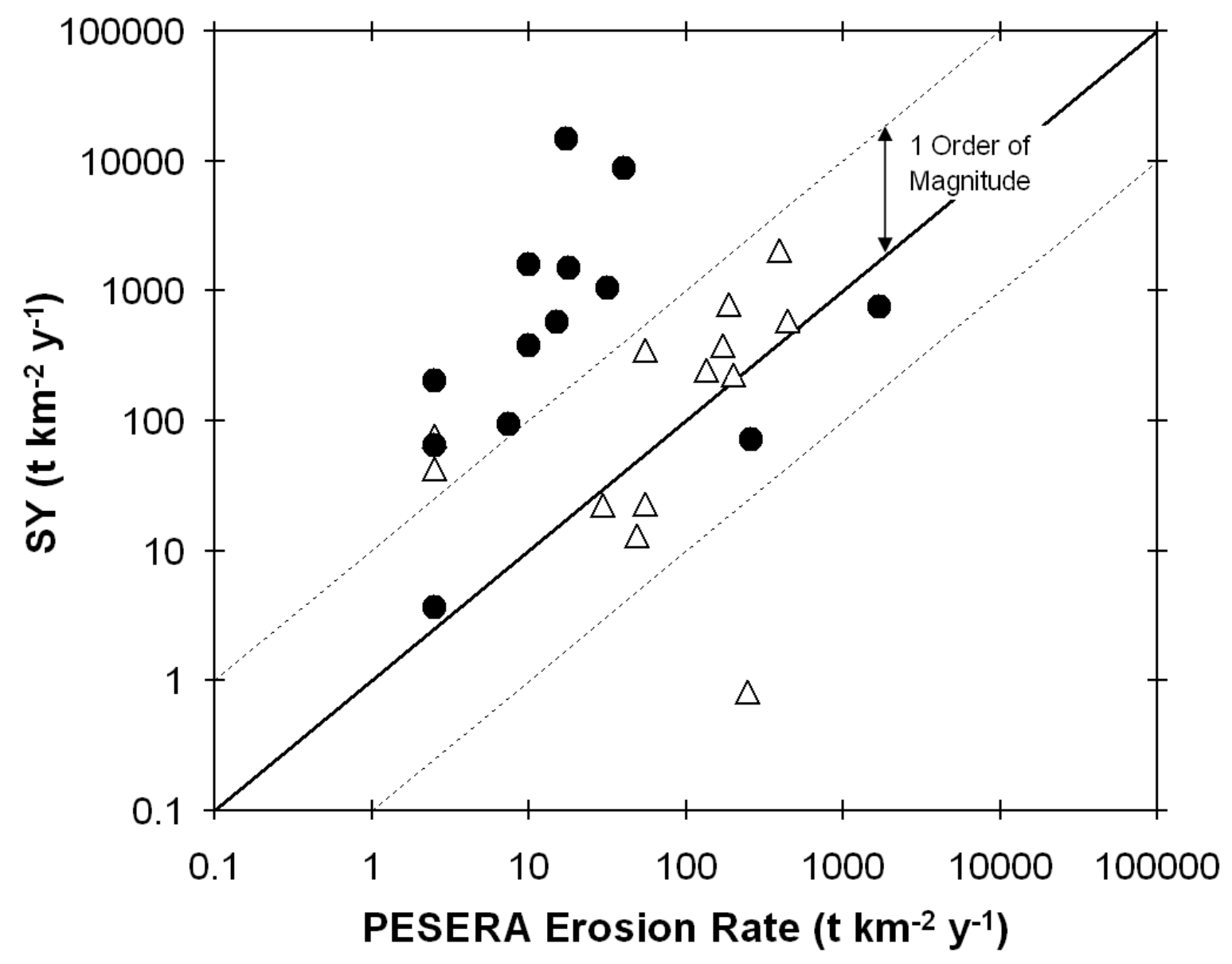

$\triangle$ Non-Mediterranean $(n=13) \quad$ Mediterranean $(n=13) \quad-1: 1$ line

Figure 2: Comparison of PESERA predicted erosion rates (Kirkby et al. 2004; 2008) with SY from some European catchments, smaller than $1 \mathrm{~km}^{2}$ (see table 2 for characteristics). Data were classified in Mediterranean and Non-Mediterranean catchments, according to the LANMAP2 climatic classification (Metzger et al. 2005; Mücher et al. 2006). 


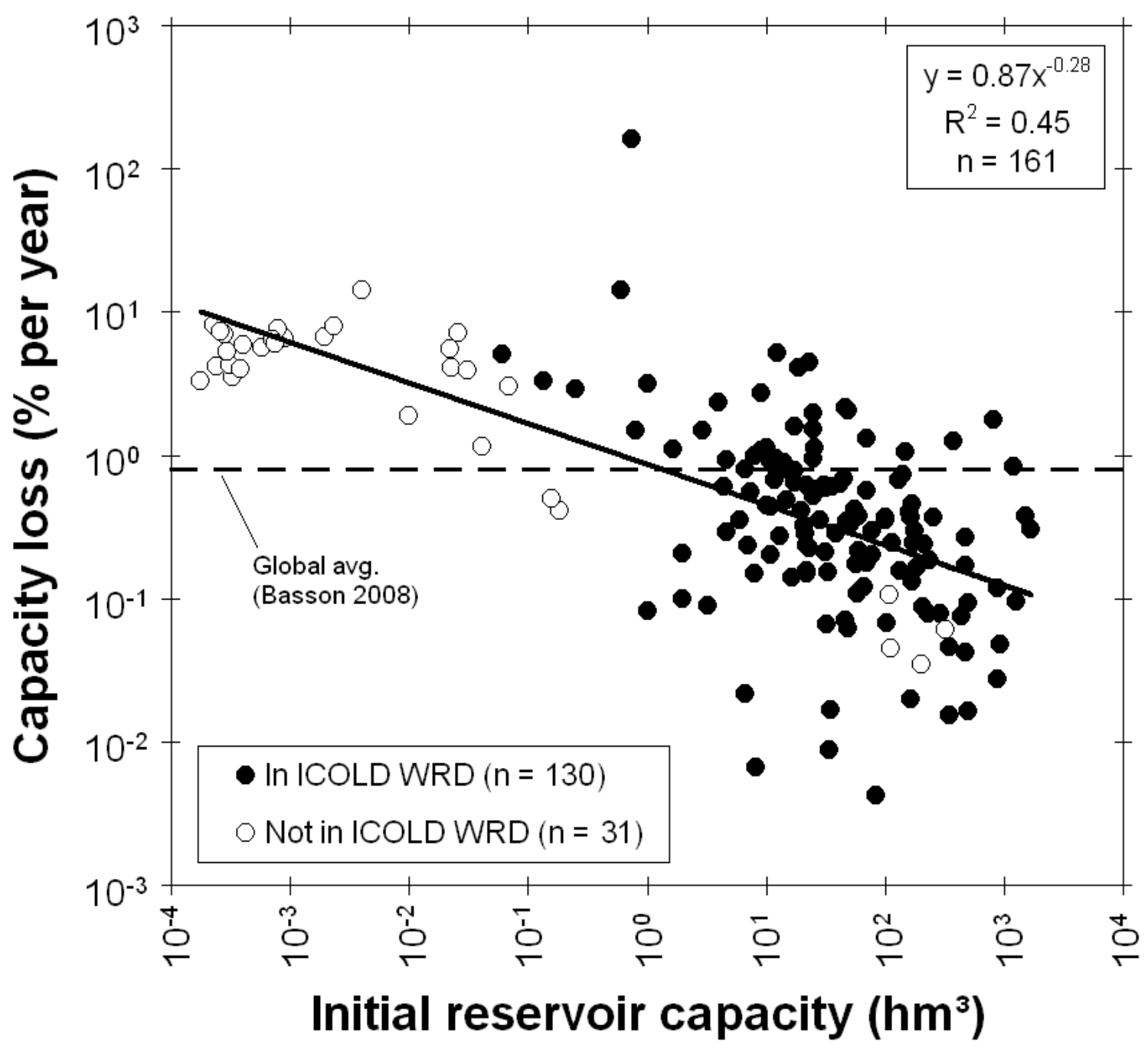

Figure 3: Annual reservoir capacity loss versus initial reservoir capacity for 161 reservoirs in Mediterranean Europe (data were derived from Verstraeten et al. 2006 and Vamaercke et al. subm.). ICOLD WRD is International Commission of Large Dams World Register of Dams. 